STRUCTURAL SCIENCE CRYSTAL ENGINEERING MATERIALS

ISSN 2052-5206

Received 28 July 2016

Accepted 4 October 2016

Edited by A. J. Blake, University of Nottingham, England

Keywords: $\beta$-tricalcium phosphate; whitlockite; calcium deficiency; X-ray diffraction; Rietveld refinement; bone substitute.

CCDC references: 1508203-1508316

Supporting information: this article has supporting information at journals.iucr.org/b

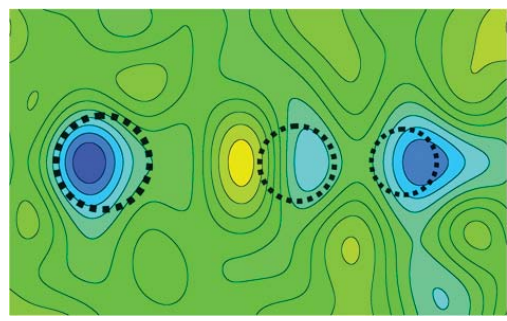

OPEN $\odot$ ACCESS

\section{Hydrogen-substituted $\beta$-tricalcium phosphate synthesized in organic media}

\author{
Christoph Stähli, ${ }^{a}$ Jürg Thüring, ${ }^{\mathrm{a}, \mathrm{b}}$ Laëtitia Galea, ${ }^{\mathrm{a}}$ Solène Tadier, ${ }^{\mathrm{c}}$ Marc Bohner $^{\mathrm{a}}$ \\ and Nicola Döbelin ${ }^{\mathrm{a}, \mathrm{d} *}$
}

${ }^{\mathbf{a}}$ RMS Foundation, Bettlach, Switzerland, ${ }^{\mathbf{b}}$ Department of Materials, ETH Zürich, Zürich, Switzerland, ${ }^{\mathbf{c}}$ MATEIS, INSALyon, Villeurbanne CEDEX, France, and Institute of Geological Sciences, University of Bern, Bern, Switzerland. *Correspondence e-mail: nicola.doebelin@rms-foundation.ch

$\beta$-Tricalcium phosphate ( $\beta$-TCP) platelets synthesized in ethylene glycol offer interesting geometries for nano-structured composite bone substitutes but were never crystallographically analyzed. In this study, powder X-ray diffraction and Rietveld refinement revealed a discrepancy between the platelet structure and the known $\beta$-TCP crystal model. In contrast, a model featuring partial $\mathrm{H}$ for $\mathrm{Ca}$ substitution and the inversion of $\mathrm{P} \mathrm{O}_{4}$ tetrahedra, adopted from the whitlockite structure, allowed for a refinement with minimal misfits and was corroborated by $\mathrm{HPO}_{4}^{2-}$ absorptions in Fourier-transform IR spectra. The $\mathrm{Ca} / \mathrm{P}$ ratio converged to $1.443 \pm 0.003(n=36)$, independently of synthesis conditions. As a quantitative verification, the platelets were thermally decomposed into hydrogen-free $\beta$-TCP and $\beta$-calcium pyrophosphate which resulted in a global $\mathrm{Ca} / \mathrm{P}$ ratio in close agreement with the initial $\beta$-TCP Ca/P ratio $(\Delta \mathrm{Ca} / \mathrm{P}=0.003)$ and with the chemical composition measured by inductively coupled plasma $(\Delta \mathrm{Ca} / \mathrm{P}=0.003)$. These findings thus describe for the first time a hydrogensubstituted $\beta$-TCP structure, i.e. a $\mathrm{Mg}$-free whitlockite, represented by the formula $\mathrm{Ca}_{21-x}\left(\mathrm{HPO}_{4}\right)_{2 x}\left(\mathrm{PO}_{4}\right)_{14-2 x}$, where $x=0.80 \pm 0.04$, and may have implications for resorption properties of bone regenerative materials.

\section{Introduction}

Calcium phosphates ( $\mathrm{CaPs}$ ) have been widely used as synthetic bone graft substitutes and exhibit excellent biocompatibility, osteoconductivity and a chemical composition similar to bone mineral (LeGeros, 2002). Sintered hydroxyapatite [HA, $\left.\mathrm{Ca}_{5}\left(\mathrm{PO}_{4}\right)_{3} \mathrm{OH}\right], \beta$-tricalcium phosphate [ $\beta$-TCP, $\left.\mathrm{Ca}_{3}\left(\mathrm{PO}_{4}\right)_{2}\right]$, or biphasic blends of the two constitute the most common commercially available $\mathrm{CaP}$ materials. In particular, $\beta$-TCP is of interest owing to its cell-mediated resorbability in vivo (Bohner, 2010).

While sintering of CaPs results in a limited range of geometries and specific surface areas, wet-chemical synthesis methods open the door to nano-sized entities and have been extensively studied for their potential in a broad range of biomedical applications including tissue engineering, drug/ gene delivery and the design of structured composites (Loomba \& Bhupinder, 2015; Makarov et al., 2010). In contrast to phases such as $\mathrm{HA}$ and brushite $\left(\mathrm{CaHPO}_{4} \cdot 2 \mathrm{H}_{2} \mathrm{O}\right), \beta$ - TCP cannot be precipitated from aqueous solutions. Only in the presence of $\mathrm{Mg}$, whitlockite [e.g. $\mathrm{Ca}_{18} \mathrm{Mg}_{2}\left(\mathrm{HPO}_{4}\right)_{2}\left(\mathrm{PO}_{4}\right)_{12}$ ], a naturally occurring mineral with a crystal structure equivalent to that of $\beta$-TCP can be synthesized at ambient or hydrothermal conditions (Hamad \& Heughebaert, 1986). Nevertheless, micron- or nano-sized (Mg-free) $\beta$-TCP particles have been obtained by precipitation in aqueous medium under autoclave conditions (Toyama et al., 2002; Galea et al., 2015) as 
well as in methanol (Bow et al., 2004) and ethylene glycol (Tao et al., 2008, 2009; Galea et al., 2013, 2014).

Precipitation in ethylene glycol between 363 and $443 \mathrm{~K}$ allowed for the synthesis of sub-micrometric uniform hexagonal $\beta$-TCP platelets with controllable geometries (Galea $e t$ al., 2013, 2014). Specifically, by modifying synthesis parameters including the solution concentration and acidity, the aspect ratio could be varied in the range of 1 to 14 with size dispersions as low as $5 \%$. Since $\mathrm{CaP}$ ceramics are inherently brittle, platelets with high aspect ratios are of particular interest as fillers in nano-structured ceramic polymer composites inspired by natural materials such as nacre, which may provide suitable properties for load-bearing bone substitutes (Tang et al., 2003). Moreover, owing to their non-agglomerating properties, crystals with an aspect ratio of 1 may enhance the flowability of $\mathrm{CaP}$ pastes or cements.

X-ray diffraction (XRD) patterns of $\beta$-TCP platelets previously revealed a poor agreement with the known $\beta$-TCP crystal model (Galea et al., 2013; Dickens et al., 1974). Recently, preliminary analysis of the platelet crystal structure indicated a sub-stoichiometric Ca-occupation. The crystal structure of a ceramic strongly influences properties including the solubility, which in turn determines the in vivo resorption of a bone graft. In particular, the dissolution rate and bone bonding properties of Ca-deficient HA [CDHA, $\mathrm{Ca}_{10-x}\left(\mathrm{HPO}_{4}\right)_{x}\left(\mathrm{PO}_{4}\right)_{6-x}(\mathrm{OH})_{2-x}$, where $\left.0<x \leq 1\right]$ were shown to depend on its $\mathrm{Ca} / \mathrm{P}$ ratio (Radin \& Ducheyne, 1993; Mavropoulos et al., 2003). Therefore, in order to successfully apply organic media-synthesized $\beta$-TCP platelets for bone regeneration, their crystal structure, and in particular the $\mathrm{Ca}-$ deficiency, must be well understood.

In this study, $\beta$-TCP platelets were examined by Rietveld refinement of powder XRD patterns as well as by Fouriertransform IR (FTIR) spectroscopy and chemical analysis. Furthermore, the effect of synthesis parameters on the platelet stoichiometry was investigated. Finally, the platelet crystal structure was discussed in comparison with sintered $\beta$-TCP and with synthetic Mg-whitlockite.

\section{Materials and methods}

\subsection{Syntheses}

$\beta$-TCP platelets were produced by adapting a previously reported precipitation method (Tao et al., 2008), either in a batch reactor as recently described (Galea et al., 2013), or in a continuous tubular reactor. Briefly, a $\mathrm{CaCl}_{2}$-ethylene glycol solution was mixed with a $\mathrm{H}_{3} \mathrm{PO}_{4}$ (or $\mathrm{Na}_{2} \mathrm{HPO}_{4}$ )-ethylene glycol solution, $\mathrm{pH}$-adjusted by $\mathrm{NaOH}$ and kept at constant temperature ( 363 to $443 \mathrm{~K}$ ) for at least $30 \mathrm{~min}$. A detailed description of the synthesis of $\beta$-TCP platelets is given in the supporting information $\S \mathrm{S} 1.1$ and an example of the resulting morphology is shown in $\S \mathrm{S} 2.1$.

Reference $\beta$-TCP materials were produced through sintering of $\mathrm{CaCO}_{3}\left(\mathrm{CaCO}_{3}\right.$, MERCK, Germany) and monetite $\left(\mathrm{CaHPO}_{4}\right.$, GFS Chemicals, USA) at 1173 to $1273 \mathrm{~K}$, resulting in $100 \% \beta$-TCP (used for FTIR analysis) or $93 \mathrm{wt} \%$
$\beta$-TCP and $7 \mathrm{wt} \%$ hydroxyapatite (HA, used for elemental analysis). Mg-whitlockite was synthesized hydrothermally by incubating $1 \mathrm{~g}$ of monetite with $20 \mathrm{ml}$ of a $1.5 \mathrm{mM} \mathrm{MgCl} 2$ solution at $473 \mathrm{~K}$ for $1 \mathrm{~d}$ in a steel autoclave lined with a Teflon capsule (inner volume of $45 \mathrm{ml}$ ).

\subsection{Crystallographic analysis}

The crystal structure of the synthesized platelets was studied by means of powder X-ray diffraction (XRD). Samples were inserted into a glass capillary (diameter: $0.5 \mathrm{~mm}$, glass type no 10; Hilgenberg GmbH, Germany) aligned and rotating on the goniometer axis in a Bruker D8 Advance diffractometer (Bruker AXS GmbH, Germany). XRD patterns were collected using digitally and $\mathrm{Ni}$-filtered $\mathrm{Cu} K \alpha$ radiation (wavelength: $1.540598 \AA$ ) in transmission geometry from 5 to $60^{\circ} 2 \theta$ at a step size of $0.012^{\circ}$ and an acquisition time of $5.75 \mathrm{~s}$ per step.

The resulting patterns were analyzed by Rietveld refinement (Rietveld, 1969) using BGMN software, Version 4.2.22 (Bergmann et al., 1998) and Profex user interface, Version 3.9.2 (Doebelin \& Kleeberg, 2015). Since varying fractions of monetite were present as a by-product of the $\beta$-TCP synthesis, a monetite phase model (Dickens et al., 1972), PDF\# 04-0093755 , was included in the refinement. Moreover, a broad signal at around $32^{\circ}(2 \theta)$ was detected in some samples and was attributed to a nanocrystalline chlorapatite phase, although no unambiguous identification of the type of apatite was possible. Consequently, the chlorapatite phase model (Hughes et al., 1989), PDF\# 04-012-1323, was included, which improved the quality of the fits. The $\beta$-TCP structure (Dickens et al., 1974), PDF\# 04-008-8714, was taken as a starting model and modified to better fit the observed patterns, as elaborated in $\$ 3$. The refinement was verified to be independent of the extent of measurement noise by comparison of two diffractograms obtained on the same sample using an acquisition time of 5.75 and $19 \mathrm{~s}$ per step, respectively. For Mg-doped platelets, the $\mathrm{Mg}$ fraction determined by elemental analysis was used to account for the lower electron density on the Ca5 position occupied by $\mathrm{Mg}$ atoms (Enderle et al., 2005). In the case of synthetic whitlockite, the Ca5 position was fully occupied with a refined $\mathrm{Mg} / \mathrm{Ca}$ ratio. The Ca4 site occupancy was refined as partially occupied with $\mathrm{Ca}$, as proposed previously (Calvo \& Gopal, 1975).

In order to monitor temperature-induced phase separations, in-situ XRD patterns were acquired using a heating chamber (Anton Paar HTK 1200, Anton Paar GmbH, Austria) in an X'Pert diffractometer in reflective geometry (X'Pert Pro MPD, Panalytical, The Netherlands) using Nifiltered $\mathrm{Cu} K \alpha$ radiation. Specifically, the temperature was raised in steps of $323 \mathrm{~K}$ from 773 to $1273 \mathrm{~K}$ and kept for $1 \mathrm{~h}$ at each step. For the quantitative phase analysis after calcination, samples were heated directly to $1273 \mathrm{~K}$ (heating rate: $17 \mathrm{~K} \mathrm{~min}^{-1}$ ) and kept at $1273 \mathrm{~K}$ for $1 \mathrm{~h}$ (or $1328 \mathrm{~K}$ for $48 \mathrm{~h}$ in the case of whitlockite). The resulting XRD patterns (obtained in transmission geometry as described earlier) were refined including the $\beta$-calcium pyrophosphate ( $\beta$-CPP, 
$\mathrm{Ca}_{2} \mathrm{P}_{2} \mathrm{O}_{7}$ ) phase model (Boudin et al., 1993), PDF\# 04-0093876. The HA phase model (Sudarsanan \& Young, 1969), PDF\# 01-074-0565, was included for the sintered reference material.

\subsection{FTIR spectroscopy}

Optically clear pellets of $13 \mathrm{~mm}$ diameter were prepared by grinding and mixing $300 \mathrm{mg} \mathrm{KBr}\left(\mathrm{KBr}\right.$, Uvasol ${ }^{\mathbb{R}}$, MERCK, Germany) with approximately $1 \mathrm{mg}$ of sample and subsequent pressing at $10 \mathrm{~T}$ for $2.5 \mathrm{~min}$ under vacuum. Transmission FTIR spectra were obtained on a Bruker Lumos IR spectrometer between 400 and $4000 \mathrm{~cm}^{-1}$ at a resolution of $4 \mathrm{~cm}^{-1}$ and 64 accumulations.

\subsection{Elemental analysis}

In order to quantify the elemental composition, samples were dissolved in $\mathrm{HNO}_{3}(69 \%$ w/w, Trace SELECT, Fluka, Switzerland) and diluted 1:100 in demineralized $\mathrm{H}_{2} \mathrm{O}$ with a final concentration of $3 \% \mathrm{HNO}_{3}$. $\mathrm{Ca}, \mathrm{P}, \mathrm{Na}$ and $\mathrm{Mg}$ concentrations were measured ( $n=6$ per sample) using inductively coupled plasma-mass spectroscopy (ICP-MS; Agilent 7700x, Agilent Technologies, Japan). ${ }^{44} \mathrm{Ca},{ }^{31} \mathrm{P},{ }^{23} \mathrm{Na}$ and ${ }^{24} \mathrm{Mg}$ signals were calibrated against certified single element standard solutions (Inorganic Ventures, USA) serially diluted to the following concentrations: (i) 100, 10 and 1 p.p.b. $\mathrm{Na}$ and (ii) 5000, 1000, 200 and 40 p.p.b. Ca combined with proportional $\mathrm{P}$ and $\mathrm{Mg}$ concentrations in a Ca:P:Mg weight ratio of 10:5:1. Additionally, calibration drifts were corrected according to a $\mathrm{Ca}-\mathrm{P}-\mathrm{Mg}$ standard measured after every 8 th sample and according to a 40 p.p.b internal $\mathrm{In} / \mathrm{Sc} / \mathrm{Bi}$ standard solution (Inorganic Ventures, USA) measured along with each sample.

Since the preparation of ICP standard solutions involves pipetting errors (approximately $\pm 2 \%$ ), the $\mathrm{Ca} / \mathrm{P}$ ratio was corrected $\left((\mathrm{Ca} / \mathrm{P})_{\text {ICP,corr }}\right)$ based on a chemically pure, hightemperature sintered $\beta$-TCP/HA reference material. Specifically, the difference between the $\mathrm{Ca} / \mathrm{P}$ ratios measured in the reference through XRD, by phase fraction quantification assuming stoichiometric phases (Ishikawa et al., 1993), and through ICP $(\mathrm{Ca} / \mathrm{P}=1.512$ and 1.486 , respectively $)$ was subtracted from all $\mathrm{Ca} / \mathrm{P}$ ratios. (The sum of the $\mathrm{Na} / \mathrm{P}, \mathrm{Mg} / \mathrm{P}$ and $\mathrm{Sr} / \mathrm{P}$ molar ratios in the reference was verified to be below 0.002.)

\section{Results}

\subsection{Crystal structure model for Rietveld refinement}

The Ca4 and $\mathrm{P} \mathrm{O}_{4}$ region of the stoichiometric $\beta$-TCP crystal structure (Dickens et al., 1974) is shown in Fig. 1(a). This structure was used as a starting model to fit XRD patterns of $\beta$-TCP platelets produced in ethylene glycol. Applying this model confirmed space group $R 3 c$ but, although refining unitcell dimensions, scale factor, crystallite size, microstrain and texture, resulted in substantial misfits of relative peak intensities between observed and calculated patterns (Fig. 1c). Difference-Fourier maps were generated to visualize the misfits in direct space electron densities using the software
Promap (Doebelin; unpublished addon for Profex; Doebelin \& Kleeberg, 2015). Most atoms showed slight displacements, which could be refined with stable convergence by defining the $\mathrm{P}_{2} \mathrm{O}_{4}$ and $\mathrm{P}_{3} \mathrm{O}_{4}$ tetrahedra as rigid bodies with the dimensions reported in the stoichiometric $\beta$-TCP model (Dickens et al., $1974)$ and with refined translation and rotation. In contrast, major discrepancies were observed for several atoms with coordinates $0,0, z$. Namely, the site occupancies of the Ca4 and $\mathrm{O} 2$ positions were lower than the stoichiometric values $(0.5$ and 1.0 , respectively), as revealed by negative differences between observed and calculated electron densities (Fig. 1e). Moreover, a negative difference at the $\mathrm{P} 1$ site and an adjacent positive region (slightly closer to the $\mathrm{Ca} 4$ site) indicated the splitting of this position into two sites. Based on the elemental analysis (see \$3.4), the lower Ca4 site occupancy cannot be explained by substitution with lighter $\mathrm{Mg}$ atoms. However, the observed arrangement showed similarities to the crystal
Refinement model (a)

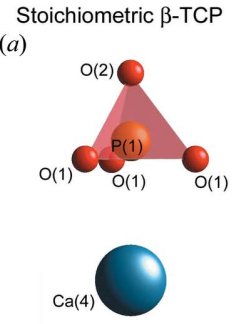

Agreement with observed structure
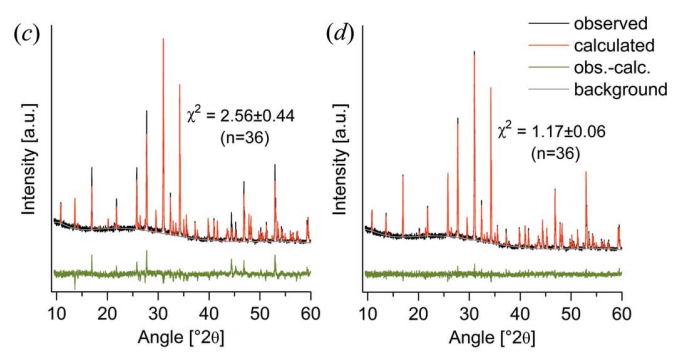

Electron density difference (obs. - calc.) [electrons / $\AA^{3}$ ] 1.38
0.00
-1.38

Figure 1

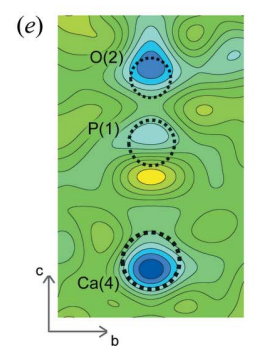

H-substituted $\beta$-TCP

(b)

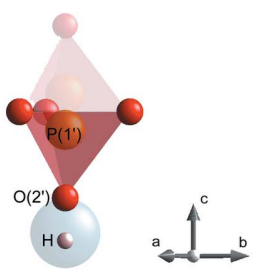

Illustration of the Ca4 and $\mathrm{P} \mathrm{O}_{4}$ atomic arrangement in $(a)$ the stoichiometric $\beta$-TCP crystal model (Dickens et al., 1974) and (b) a hydrogen-substituted $\beta$-TCP model where some of the $\mathrm{P}^{\mathrm{O}} \mathrm{O}_{4}$ tetrahedra are inverted and protonated. Representative XRD patterns of $\beta$-TCP platelets fitted by Rietveld refinement with $(c)$ the stoichiometric and $(d)$ the hydrogen-substituted crystal model. (Monetite and chlorapatite fractions were negligible in this sample and were not refined for the purpose of this illustration.) The difference (green line) between the observed (black) and calculated (red) intensity, characterized by $\chi^{2}$ values, was larger for the stoichiometric compared with the hydrogensubstituted model. EDD maps between the observed structure and $(e)$ the structure calculated with the stoichiometric model indicated suboccupied $\mathrm{O} 2, \mathrm{P} 1$ and $\mathrm{Ca} 4$ sites along with a positive region immediately below the P1 site, while $(f)$ using the hydrogen-substituted model resulted in much smaller EDDs. 
structure of whitlockite, previously described using singlecrystal XRD structure refinements (Calvo \& Gopal, 1975). In their model, the Ca4 position was sub-occupied and the $\mathrm{P}_{4} \mathrm{O}_{4}$ tetrahedron (comprising $\mathrm{P} 1$, three $\mathrm{O} 1$ and one $\mathrm{O} 2$ atom) was protonated and mirrored about the $\mathrm{O} 1$ base plane, resulting in a new $\mathrm{P}^{\prime}$ position and a new $\mathrm{O}_{2}^{\prime}$ site connected to a $\mathrm{H}$ atom (Fig. 1b).

The resolution of the powder XRD data was not sufficient to unambiguously identify individual atomic species and site occupancies simultaneously. In particular, since the $\mathrm{O} 2^{\prime} \mathrm{H}$ group of the flipped tetrahedron strongly overlapped with residual $\mathrm{Ca}$ on the $\mathrm{Ca} 4$ position, independent refinement of $\mathrm{Ca} 4$ deficiency and the number of flipped tetrahedra was not possible. However, adopting the model of inverted tetrahedra (Calvo \& Gopal, 1975) allowed restrictions to be applied to eventually describe the structure by refining one single parameter. Specifically, as the tetrahedra could only flip as a whole, the fraction of inverted $\mathrm{P} \mathrm{O}_{4}$ tetrahedra, $f_{m}$, was defined and linked to the individual site occupancies, $P$, as follows: $P_{\mathrm{P}^{\prime}}=$ $P_{\mathrm{O} 2^{\prime}}=P_{\mathrm{H}}=f_{m}$ and $P_{\mathrm{P} 1}=P_{\mathrm{O} 2}=1-f_{m}$. Moreover, in order to maintain charge balance, two tetrahedra were inverted and protonated for each missing $\mathrm{Ca}^{2+}$ ion, i.e. $P_{\mathrm{Ca} 4}=\left(1-f_{m}\right) / 2$. The resulting model for refined site occupancies also restricted the overlapping sites $P_{\mathrm{Ca} 4}+P_{\mathrm{O} 2^{\prime}}$ to a maximum total occupancy of 1 . Thus, taking into account all atomic positions in the $\beta$-TCP unit cell (6 $\mathrm{P} 1$ positions for $42 \mathrm{P}$ positions in total), the general formula of the structure is $\beta-\mathrm{Ca}_{21-f m}\left(\mathrm{HPO}_{4}\right)_{2 \mathrm{fm}^{-}}$ $\left(\mathrm{PO}_{4}\right)_{14-2 f m}$. The $\mathrm{P} \mathrm{O}_{4}$ tetrahedra were treated as semi-rigid bodies by applying the following restrictions: the $z$-distance $z_{\mathrm{P}^{\prime}}-\mathrm{z}_{\mathrm{O} 1}$ was linked to $z_{\mathrm{P} 1}-z_{\mathrm{O} 1}$, while $z_{\mathrm{P} 1^{\prime}}-z_{\mathrm{O} 2^{\prime}}$ and $z_{\mathrm{P} 1}-z_{\mathrm{O} 2}$ were set equal to $0.1498 \mathrm{~nm}$ (Dickens et al., 1974) and $z_{\mathrm{O} 2^{\prime}}-z_{\mathrm{H}}$ to $0.0942 \mathrm{~nm}$ (Calvo \& Gopal, 1975). The $x_{\mathrm{O} 1}$ and $y_{\mathrm{O} 1}$ coordinates could be refined without resulting in extensive distortion of the tetrahedra. Temperature factors were taken from the stoichiometric $\beta$-TCP model (Dickens $e t$ $a l ., 1974)$ and multiplied by a refined scale factor common for each type of atom.

This model was first validated by refining an XRD pattern of hydrothermally synthesized $\mathrm{Mg}$-whitlockite, which resulted in a good fit $\left(\chi^{2}=1.11\right.$; defined previously; Toby, 2006) and a stable convergence to an $f_{m}$ value of $0.932 \pm 0.009$, i.e. $P_{\mathrm{Ca} 4}=$ $0.034 \pm 0.004$ and $(\mathrm{Ca}+\mathrm{Mg}) / \mathrm{P}=1.433 \pm 0.001$, where the errors represent the estimated standard deviation (e.s.d.) calculated by the refinement algorithm. This stoichiometry thus corresponds well with the theoretical composition of synthetic $\mathrm{Mg}$-whitlockite: $\mathrm{Ca}_{18} \mathrm{Mg}_{2}\left(\mathrm{HPO}_{4}\right)_{2}\left(\mathrm{PO}_{4}\right)_{12}$, $(\mathrm{Ca}+\mathrm{Mg}) / \mathrm{P}=1.429$ (Gopal et al., 1974). Note that the composition was also closely matched by ICP-MS analysis $\left[(\mathrm{Ca} / \mathrm{P})_{\mathrm{ICP}, \text { corr }}=1.265,(\mathrm{Mg} / \mathrm{P})_{\mathrm{ICP}}=0.156\right.$, i.e. $((\mathrm{Ca}+\mathrm{Mg}) / \mathrm{P})_{\mathrm{ICP}}$ $=1.421]$. Moreover, the refinement confirmed that the Ca5 position in synthetic whitlockite was occupied exclusively by $\mathrm{Mg}$ which is in line with the theoretical composition and previous studies (Enderle et al., 2005).

Using the same model to refine the structure of $\beta$-TCP platelets grown in organic media allowed for much better fits compared with the published model, as reflected in lower $\chi^{2}$ values (detailed in Table 1) and smaller electron density
Table 1

XRD data acquisition parameters, refinement statistics, space group and unit-cell constants.

Radiation, wavelength $(\AA)$

$2 \theta$ range $\left(^{\circ}\right)$

$\mathrm{Cu} K \alpha, 1.540598$

Step scan increment $\left({ }^{\circ} 2 \theta\right)$

$5-60$

0.012

Refinement statistics $\dagger$

$R_{\mathrm{wp}}(\%)$, defined previously (McCusker et al., 1999) $\quad 6.4 \pm 0.6$

$R_{\exp }(\%)$ (McCusker et al., 1999)

$\chi^{2}=\left(R_{\mathrm{wp}} / R_{\mathrm{exp}}\right)^{2}$, defined previously (Toby, 2006)

$5.9 \pm 0.6$

$1.17 \pm 0.06$

Unit cell $\dagger$

Space group

$a(\AA)$

$c(\AA)$

$R 3 c$

$10.471 \pm 0.006$ $37.371 \pm 0.012$

$\dagger$ Mean values and standard deviations from 36 samples.

differences (EDDs; Figs. $1 d$ and $f$ ). The $f_{m}$ value thereby converged to $0.801 \pm 0.041$ (average and SD over 36 samples), corresponding to a $P_{\mathrm{Ca} 4}$ of $0.100 \pm 0.021$ and a $\beta$-TCP Ca/P ratio of $1.443 \pm 0.003$. (The dependence of the stoichiometry on synthesis parameters is $\S 3.5$.) Table 2 summarizes the site occupancies as well as the atomic coordinates of the $\mathrm{Ca} 4$ position and the original and inverted $(\mathrm{H}) \mathrm{P} \mathrm{O}_{4}$ tetrahedra. All refined structures and diffraction raw data are provided in crystallographic information files (CIF) as supporting information along with a sample list (Table S2) matching the synthesis condition numbers with the name of the datablocks in the CIFs.

\subsection{FTIR analysis}

The phosphate absorption region in the FTIR spectra of sintered $\beta$-TCP as well as $\beta$-TCP platelets is shown in Fig. 2 . (The full wavenumber range is presented in the supporting information $\S \mathrm{S} 2.2$; Fig. S2). The absorption bands observed in sintered $\beta$-TCP are consistent with previous reports (Jillavenkatesa \& Condrate, 1998; Berzina-Cimdina \& Borodajenko, 2012; Bigi et al., 1997). Specifically, the bands at

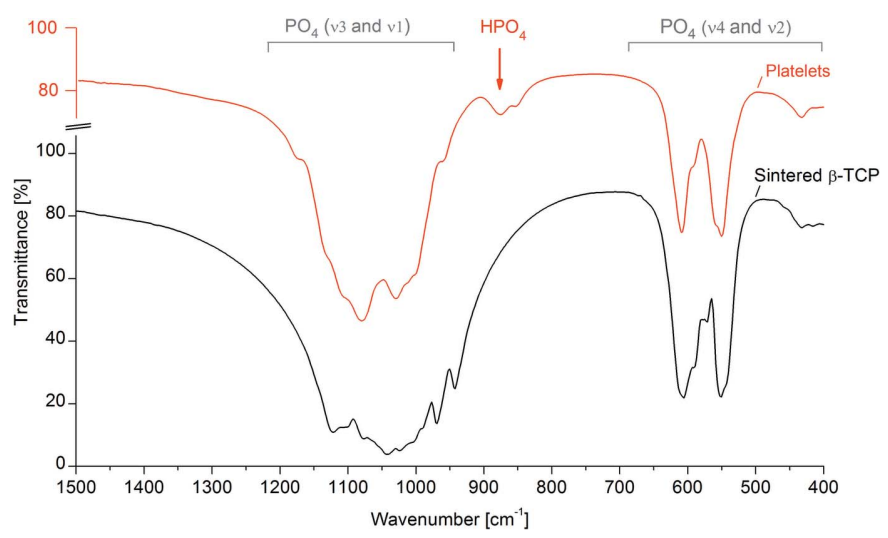

Figure 2

Transmission FTIR spectra of sintered $\beta$-TCP and $\beta$-TCP platelets. The phosphate absorption regions show several differences in relative peak intensity and/or peak shifts between the two materials. Platelets but not sintered $\beta$-TCP exhibited an absorption band at $875 \mathrm{~cm}^{-1}$, attributable to $\mathrm{HPO}_{4}^{2-}$ groups. 
Table 2

Site occupancies and atomic coordinates for the original and mirrored $(\mathrm{H}) \mathrm{P} \mathrm{O}_{4}$ tetrahedron.

\begin{tabular}{|c|c|c|c|c|}
\hline \multirow[b]{2}{*}{ Atom } & \multirow[b]{2}{*}{ Occupancy $\dagger$} & \multicolumn{3}{|c|}{ Atomic coordinates $\dagger$ (as fractions of the unit-cell constants) } \\
\hline & & $x$ & $y$ & $z$ \\
\hline $\mathrm{Ca} 4$ & $0.100 \pm 0.021$ & 0 & 0 & $-0.0843 \pm 0.0024$ \\
\hline \multicolumn{5}{|c|}{ Original $\mathrm{P} \mathrm{O}_{4}$ tetrahedron } \\
\hline P1 & $0.199 \pm 0.041$ & 0 & 0 & 0 \\
\hline $\mathrm{O} 1$ & 1 & $0.0126 \pm 0.0037$ & $-0.1345 \pm 0.0041$ & $-0.0104 \pm 0.0009$ \\
\hline $\mathrm{O} 2$ & $0.199 \pm 0.041$ & 0 & 0 & $0.0401 \pm 0.0000$ \\
\hline \multicolumn{5}{|c|}{ Mirrored $\mathrm{HP}^{\prime} \mathrm{O}_{4}$ tetrahedron } \\
\hline $\mathrm{P}^{\prime}$ & $0.801 \pm 0.041$ & 0 & 0 & $-0.0209 \pm 0.0018$ \\
\hline $\mathrm{O} 1$ & 1 & $0.0126 \pm 0.0037$ & $-0.1345 \pm 0.0041$ & $-0.0104 \pm 0.0009$ \\
\hline $\mathrm{O} 2^{\prime}$ & $0.801 \pm 0.041$ & 0 & 0 & $-0.0610 \pm 0.0018$ \\
\hline $\mathrm{H}$ & $0.801 \pm 0.041$ & 0 & 0 & $-0.0862 \pm 0.0018$ \\
\hline
\end{tabular}

$\dagger$ Mean values and standard deviations from 36 samples.

approximately $1120,1105,1080,1042$ and $1025 \mathrm{~cm}^{-1}$ can be assigned to the $v_{3}$ vibrational mode of the $\mathrm{PO}_{4}^{3-}$ ion. Moreover, $v_{1}-\mathrm{PO}_{4}$ bands were observed at 970 and $942 \mathrm{~cm}^{-1}, v_{4}-$ $\mathrm{PO}_{4}$ bands at $605,592,545$ and $552 \mathrm{~cm}^{-1}$ and two weak $\nu_{2}-\mathrm{PO}_{4}$ bands at 415 and $435 \mathrm{~cm}^{-1}$. Additional weak absorptions, e.g. at $572 \mathrm{~cm}^{-1}$, also agree with previously reported $\beta$-TCP spectra (Bigi et al., 1997).

The $\mathrm{PO}_{4}$ absorption bands in spectra of $\beta$-TCP platelets differ significantly from sintered $\beta$-TCP. Specifically, several bands in the $v_{3}, v_{4}$ and $v_{2}$ region may have undergone slight chemical shifts compared with sintered $\beta$-TCP or either appeared or disappeared due to changes in relative intensities. The two $v_{1}$ absorption bands disappeared in $\beta$-TCP platelets while new shoulders were observed at 960 and $1175 \mathrm{~cm}^{-1}$ (not matched by previously reported data). The absorption band at $875 \mathrm{~cm}^{-1}$ can be assigned to $\mathrm{HPO}_{4}^{2-}$ groups, as previously observed in CDHA before sintering (Lin et al., 1998, 2001; Cantwell et al., 2014; Durucan \& Brown, 2000). The shoulder at $855 \mathrm{~cm}^{-1}$ coincides with previous attributions to $\mathrm{HPO}_{4}^{2-}$ groups in $\beta$-TCP synthesized under autoclave conditions (Toyama et al., 2002) and in synthetic whitlockite (LeGeros et al., 1989). Although $\mathrm{CO}_{3}$ absorptions have been reported close to $875 \mathrm{~cm}^{-1}$, the presence of $\mathrm{CO}_{3}$ species in the platelets can be ruled out due to the absence of any absorption bands in the $1420-1450 \mathrm{~cm}^{-1}$ region (Fowler, 1974; Sader et al., 2013). Moreover, comparison of the spectra of $\beta$-TCP platelets to those of pure monetite $\left(\mathrm{CaHPO}_{4}\right)$ and to platelet samples containing high monetite fractions demonstrated that the $\mathrm{HPO}_{4}^{2-}$ signal did not originate from the monetite phase (elaborated in the supporting information $\S \mathrm{S} 2.2$; Fig. S3). Similarly, the intensity of the $\mathrm{HPO}_{4}^{2-}$ signal was verified to be independent of the fraction of chlorapatite in the sample. Finally, comparison of spectra before and after calcination at $673 \mathrm{~K}$, as well as of pure ethylene glycol and ethanol confirmed that no signals from organic residues were detectable in the platelets. Therefore, these findings corroborate the $\mathrm{H}$ for $\mathrm{Ca}$ substitution in the $\beta$-TCP phase indicated by XRD analysis.

\subsection{Quantification of thermally} induced phase changes

In order to examine the thermal stability of the Ca-deficient $\beta$-TCP phase, XRD patterns were acquired during and after calcination, which revealed the presence of $\gamma$-CPP (PDF\# 00-017-0499) above $773 \mathrm{~K}$ and $\beta$-CPP (PDF\# 04-009-3876) between 1073 and $1273 \mathrm{~K}$ as well as after returning to room temperature (Fig. 3). Note that the patterns obtained in situ during stepwise heating could not be refined due to the unknown crystal structure of the $\gamma$-CPP phase. Extensive peak shifts due to thermal expansion of the unit cells and the sample holder, the latter resulting in a sample height displacement error, were also observed. The $\mathrm{Ca} /$ $\mathrm{P}$ ratios as well as phase fractions determined by Rietveld refinement before and after calcination at $1273 \mathrm{~K}$ are given in Table 3. Before calcination, the overall $\mathrm{Ca} / \mathrm{P}$ ratio $(1.437 \pm 0.003)$, calculated based on the weight fraction and molecular mass of each phase, was slightly lower than the refined $\beta$-TCP Ca/P ratio $(1.445 \pm 0.001)$ due to the presence of monetite $(\mathrm{Ca} / \mathrm{P}=1.0)$. After calcination, the refinement determined a $\beta$-TCP $\mathrm{Ca} / \mathrm{P}$ ratio equal to the stoichiometric value of 1.5 . This increase in the $\beta$-TCP $\mathrm{Ca} / \mathrm{P}$ ratio was compensated for by the appearance of approximately $10 \mathrm{wt} \%$ $\beta$-CPP $(\mathrm{Ca} / \mathrm{P}=1.0$, Table 3$)$, where the resulting overall $\mathrm{Ca} / \mathrm{P}$ ratio was in close agreement with the overall $\mathrm{Ca} / \mathrm{P}$ ratio determined before calcination (difference: $0.2 \%$ ). In summary, the thermal treatment induced a phase separation of $\mathrm{Ca}$ deficient hydrogen-substituted $\beta$-TCP, along with the small quantities of monetite, into stoichiometric $\beta$-TCP and $\beta$-CPP,

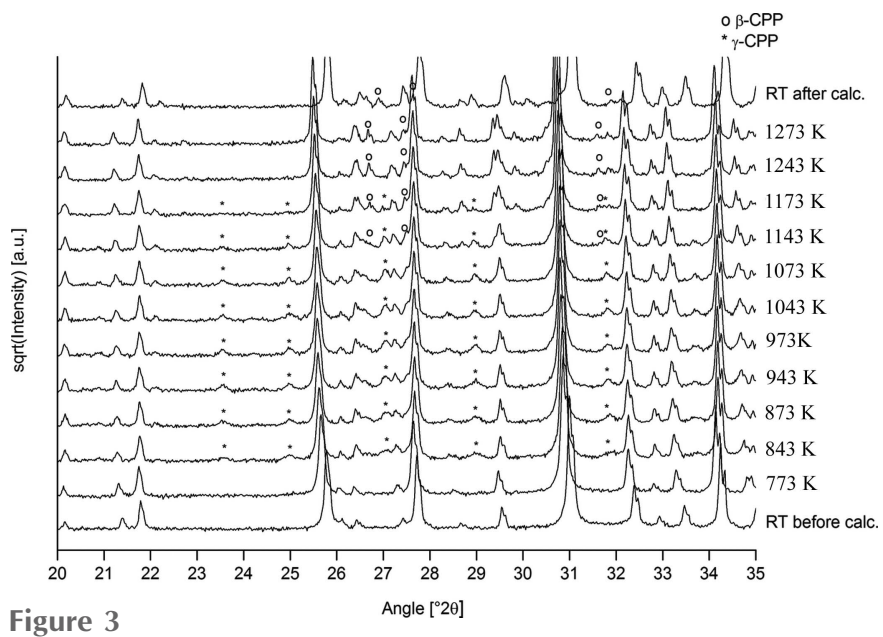

Figure 3

XRD patterns of $\beta$-TCP platelets before, during and after calcination up to $1273 \mathrm{~K}$ (RT: room temperature). Note that peak shifts are due to thermal expansion of the crystal lattice. In addition to the predominant $\beta$ TCP phase (non-labelled peaks), $\gamma$-CPP was observed between 823 and $1123 \mathrm{~K}$ whereas $\beta$-CPP appeared at $1123 \mathrm{~K}$ and also remained stable up to $1273 \mathrm{~K}$ after cooling to room temperature. 
Table 3

Comparison of the $\beta$-TCP Ca/P molar ratio, phase weight fractions $\left(f_{\mathrm{w}}\right)$ and overall (over all phases, excluding chlorapatite) $\mathrm{Ca} / \mathrm{P}$ ratio before and after calcination.

Mean values and standard deviations (SD) from three samples (synthesized using standard conditions or $443 \mathrm{~K}$ ), determined by XRD and Rietveld refinement with the hydrogen-substituted model.

\begin{tabular}{|c|c|c|c|c|c|c|}
\hline & & \multirow{2}{*}{$\begin{array}{l}\mathrm{Ca} / \mathrm{P} \\
\beta \text {-TCP }\end{array}$} & \multicolumn{3}{|l|}{$f_{\mathrm{w}}(\%)$} & \multirow{2}{*}{$\begin{array}{l}\mathrm{Ca} / \mathrm{P} \\
\text { Overall }\end{array}$} \\
\hline & & & $\beta$-ТCP & Monetite & $\beta$-СРP & \\
\hline \multirow[t]{2}{*}{ Pre-calcination } & Mean $(n=3)$ & 1.445 & 98.4 & 1.6 & - & 1.437 \\
\hline & SD & \pm 0.001 & \pm 0.8 & \pm 0.8 & - & \pm 0.003 \\
\hline \multirow[t]{4}{*}{ Post calcination } & Mean $(n=3)$ & 1.500 & 89.9 & - & 10.1 & 1.440 \\
\hline & SD & \pm 0.000 & \pm 1.1 & - & \pm 1.1 & \pm 0.006 \\
\hline & & & \multicolumn{3}{|c|}{ Difference (post - pre calc.) } & 0.003 \\
\hline & & & & & SD & \pm 0.003 \\
\hline
\end{tabular}

Table 4

The chemical composition measured by ICP before and after calcination and comparison with the overall $\mathrm{Ca} / \mathrm{P}$ ratio determined by XRD (see Table 3 ).

Mean molar ratios and standard deviations (SD) from three samples synthesized using standard conditions or $443 \mathrm{~K}$.

\begin{tabular}{|c|c|c|c|c|c|c|}
\hline & \multicolumn{4}{|l|}{ ICP } & \multirow{2}{*}{$\begin{array}{l}\Delta(\mathrm{ICP}-\mathrm{XRD}) \\
\left(\mathrm{Ca} a_{\mathrm{eq}} / \mathrm{P}\right)_{\mathrm{ICP}, \text { corr }}-(\mathrm{Ca} / \mathrm{P})_{\mathrm{XRD}}\end{array}$} \\
\hline & & $(\mathrm{Ca} / \mathrm{P})_{\mathrm{ICP}, \text { corr }}^{\dagger}{ }^{\dagger}$ & $(\mathrm{Na} / \mathrm{P})_{\mathrm{ICP}}$ & $(\mathrm{Mg} / \mathrm{P})_{\mathrm{ICP}}$ & $\left(\mathrm{Ca}_{\mathrm{eq}} / \mathrm{P}\right)_{\mathrm{ICP}, \mathrm{corr}}$ & \\
\hline Pre calc. & $\begin{array}{l}\text { Mean }(n=3) \\
\text { SD }\end{array}$ & $\begin{array}{l}1.380 \\
\pm 0.010\end{array}$ & $\begin{array}{l}0.018 \\
\pm 0.004\end{array}$ & $\begin{array}{l}0.001 \\
\pm 0.000\end{array}$ & $\begin{array}{l}1.391 \\
\pm 0.009\end{array}$ & $\begin{array}{l}-0.047 \\
\pm 0.006\end{array}$ \\
\hline Post calc. & $\begin{array}{l}\text { Mean }(n=3) \\
\text { SD }\end{array}$ & $\begin{array}{l}1.432 \\
\pm 0.001\end{array}$ & $\begin{array}{l}0.007 \\
\pm 0.000\end{array}$ & $\begin{array}{l}0.002 \\
\pm 0.001\end{array}$ & $\begin{array}{l}1.437 \\
\pm 0.001\end{array}$ & $\begin{array}{l}-0.003 \\
\pm 0.007\end{array}$ \\
\hline
\end{tabular}

$\dagger$ Corrected as described in $\S 2.4$. $\neq$ Ca-equivalent ratio, to account for substitutional cations as defined in $\S 3.4$.

while maintaining the bulk $\mathrm{Ca} / \mathrm{P}$ ratio. Good agreement of the $\mathrm{Ca} / \mathrm{P}$ ratios determined from stoichiometric phase quantities after thermal treatment and from the structure refinement of hydrogen-substituted $\beta$-TCP prior to calcination thus corroborates the accuracy of the hydrogen-substituted refinement model.

\subsection{Elemental composition}

The elemental composition of the platelets was assessed by ICP-MS in order to provide a second verification of the Rietveld refinement results (Table 4). Along with $\mathrm{Ca}$ and $\mathrm{P}$ concentrations (corrected as described in \$2.4), $\mathrm{Na}$ and $\mathrm{Mg}$ concentrations were quantified because of the addition of $\mathrm{NaOH}$ to the reaction and due to possible $\mathrm{Mg}$ traces in the $\mathrm{CaCl}_{2}$ precursor. Calcination at $1273 \mathrm{~K}$ resulted in an increase of the $\mathrm{Ca} / \mathrm{P}$ ratio and a strong decrease of the $\mathrm{Na} / \mathrm{P}$ ratio, which is possibly related to the elimination of $\mathrm{Na}^{+}$and $\mathrm{PO}_{4}^{3-}$ ions bound to volatile organic residues on the crystal surface, although below the sensitivity of FTIR analysis as stated earlier. In particular, covalent bonding between phosphates and ethylene glycol chains has been reported previously (Penczek et al., 2015).

The small quantities of $\mathrm{Na}$ and $\mathrm{Mg}$ atoms measured after calcination were likely present in the crystal structure of the as-synthesized platelets where they are known to substitute for Ca (Enderle et al., 2005; Yoshida et al., 2006). These atoms thus contribute to the total electron density which is interpreted as Ca occupancy by the refinement model described in $\S 3.1$ (except for $\mathrm{Mg}$-doped platelets and whitlockite). Note that, based on the atomic number, charge and the concentration of $\mathrm{Na}$ and $\mathrm{Mg}$ cations determined by ICP, their influence on the determination of the $f_{m}$ value by the refinement was verified to be negligible. For comparison with the $\mathrm{Ca} / \mathrm{P}$ ratio determined by $\mathrm{XRD}$, a Caequivalent ratio, $\left(\mathrm{Ca}_{\mathrm{eq}} / \mathrm{P}\right)_{\mathrm{ICP}, \mathrm{corr}}$, taking into account these trace elements, was calculated according to the number of electrons per cation, i.e. $\left(\mathrm{Ca}_{\mathrm{eq}} / \mathrm{P}\right)_{\text {ICP,corr }}=(\mathrm{Ca} / \mathrm{P})_{\text {ICP,corr }}$ $+10 / 18 \times(\mathrm{Na} / \mathrm{P})_{\mathrm{ICP}}+10 / 18 \times(\mathrm{Mg} /$ $\mathrm{P})_{\text {ICP. }}$ (The suffix 'corr' is explained in §2.4.) Before calcination, $\left(\mathrm{Ca}_{\mathrm{eq}} /\right.$ $\mathrm{P})_{\text {ICP,corr }}$ was significantly lower than $(\mathrm{Ca} / \mathrm{P})_{\mathrm{XRD}}$, which is plausible if some $\mathrm{PO}_{4}^{3-}$ ions were present outside the crystalline phase. In contrast, after calcination there was only a small difference between ICP and XRD values $(0.2 \%)$, which was lower than the standard deviation over the

three samples.

\subsection{Effect of synthesis conditions}

In order to investigate the role of synthesis conditions in the crystallization of the hydrogen-substituted structure, the reaction temperature, precursor $\mathrm{Ca} / \mathrm{P}$ ratio and total concentration, acidity, $\mathrm{Mg}$ doping, reaction time and solvent type were varied (detailed in Table S1). None of the investigated synthesis parameters had a significant effect on the $\beta$-TCP Ca/ $\mathrm{P}$, or $(\mathrm{Ca}+\mathrm{Mg}) / \mathrm{P}$, ratio determined by XRD and Rietveld refinement (Fig. 4). A statistical analysis of this data is elaborated in the supporting information $\S \mathrm{S} 2.3$.

\section{Discussion}

This study examined the particular features distinguishing the crystal structure of $\beta$-TCP platelets synthesized in ethylene glycol from high-temperature sintered, stoichiometric $\beta$-TCP. For this purpose, the structure was analyzed by means of Rietveld refinement of XRD patterns, along with IR spectroscopy and chemical analysis.

Refinement of the platelet structure using the published $\beta$ TCP crystal model (Dickens et al., 1974) revealed significant discrepancies at the $\mathrm{Ca} 4, \mathrm{P} 1$ and $\mathrm{O} 2$ crystallographic positions. On the other hand, much better fits were achieved by adopting 
a model containing a $\mathrm{Ca} 4$ deficiency along with the inversion and protonation of $\mathrm{P} \mathrm{O}_{4}$ tetrahedra. Given the major changes in site occupancy factors at the $\mathrm{Ca} 4$ and $\mathrm{O} 2$ positions compared with stoichiometric $\beta$-TCP, some displacement of other atoms was expected. Therefore, the fractional coordinates of all atomic sites were refined while treating phosphate tetrahedra as rigid bodies with some translational and rotational freedom. These lattice distortions were in line with the observed differences in the $\mathrm{PO}_{4}$ absorption bands in FTIR spectra. Moreover, the refined unit-cell constants were slightly different $(<0.4 \%$ ) from the published $\beta$-TCP model (Dickens et al., 1974). These dimensions are in agreement with previous measurements of interplanar distances in ethylene glycolsynthesized $\beta$-TCP, which were not precise enough to detect the deviation from the published structure (Tao et al., 2008).

While the resolution of powder diffraction data alone is not sufficient to distinguish between the presence of $\mathrm{H}$ atoms and vacancies, several findings corroborated the proposed model of inverted $\mathrm{HPO}_{4}^{2-}$ groups. A preliminary model involving vacancies on both the $\mathrm{Ca} 4$ and $\mathrm{O} 2$ positions without further rearrangement was considered. However, the resulting fit with the observed structure was less precise compared with the model involving inverted $\mathrm{HPO}_{4}^{2-}$ tetrahedra. The presence of $\mathrm{HPO}_{4}^{2-}$ groups was further supported by the absorption band at $875 \mathrm{~cm}^{-1}$ observed in the FTIR spectra. Moreover, this model was previously shown to allow for successful refinement of a whitlockite crystal structure (Calvo \& Gopal, 1975). Whitlockite crystallizes in space group $R 3 c$ with a unit cell equivalent to that of $\beta$-TCP and can be described by the idealized formula $\mathrm{Ca}_{18}\left(M^{2+}\right)_{2}\left(\mathrm{HPO}_{4}\right)_{2}\left(\mathrm{PO}_{4}\right)_{12}$, where $M^{2+}$ is a divalent cation substituting for $\mathrm{Ca}^{2+}$, typically $\mathrm{Mg}^{2+}$ (Calvo \& Gopal, 1975; Jang et al., 2014). Here, a hydrothermally synthesized Mg-whitlockite was refined with minimal mismatch using the described model, resulting in a stoichiometry closely matching the synthetic whitlockite formula. Therefore, the mechanism of the $\mathrm{H}$ for $\mathrm{Ca}$ substitution and inversion of the tetrahedron appear to be identical in both

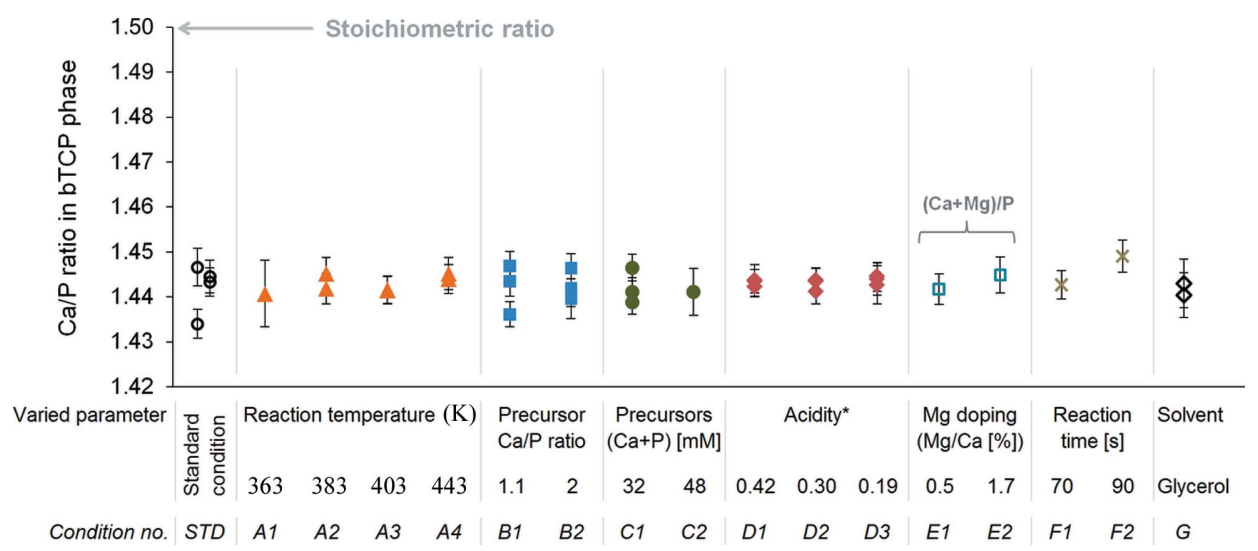

Figure 4

$\beta$-TCP Ca/P ratios determined by Rietveld refinement with the hydrogen-substituted model. The platelet synthesis conditions are detailed in Table S1. Error bars designate two times the e.s.d. (95\% confidence interval) determined by the refinement algorithm. The average $\mathrm{Ca} / \mathrm{P}$ ratio was equal to $1.443 \pm 0.003$ $(\mathrm{SD} ; n=36)$ with no significant effect of any of the investigated synthesis parameters. whitlockite and $\beta$-TCP platelets. The platelet crystal structure can thus be defined both as Mg-free whitlockite or, in other words, hydrogen-substituted $\beta$-TCP. However, in contrast to synthetic whitlockite, not all of the $\mathrm{P} 1 \mathrm{O}_{4}$ tetrahedra were inverted in platelets $\left(f_{m}=0.80 \pm 0.04\right)$. Interestingly, a similar fraction has been reported in a naturally occurring whitlockite, described by the formula $\mathrm{Ca}_{18.19}\left(\mathrm{Mg}_{1.17} \mathrm{Fe}_{0.83}\right) \mathrm{H}_{1.62}\left(\mathrm{PO}_{4}\right)_{14}$ (i.e. $\left.f_{m}=0.81\right)$, which can be explained by a solid solution of synthetic whitlockite and merrilite (e.g. $\mathrm{Mg}$ - and Na-substituted $\beta$-TCP) structure (Calvo \& Gopal, 1975; Hughes et al., 2008).

Whitlockite precipitates from aqueous solutions at ambient or hydrothermal conditions, provided that $\mathrm{Mg}$ is available (Hamad \& Heughebaert, 1986). In contrast, in the absence of $\mathrm{Mg}$, phases including brushite, CDHA or HA are more stable than the $\beta$-TCP structure (Dorozhkin \& Epple, 2002). Therefore, Mg-free $\beta$-TCP was never observed to precipitate from aqueous solutions, but forms above $1073 \mathrm{~K}$ by decomposition of CDHA or by solid-state reactions (Gibson et al., 2000). Nevertheless, pure $\beta$-TCP has been produced from amorphous calcium phosphate precursors under autoclave conditions at $493 \mathrm{~K}$ (Toyama et al., 2002), while $\alpha$-TCP was transformed at 423 to $473 \mathrm{~K}$ into a biphasic mixture of CDHA and up to $20 \% \beta$-TCP (Galea et al., 2015). A higher stability of $\beta$-TCP at elevated temperatures is in line with the fact that the solubility of $\beta$-TCP decreases more strongly with increasing temperature (between 298 and $363 \mathrm{~K}$ ) compared with HA, brushite and monetite (Vereecke \& Lemaître, 1990). Moreover, a higher temperature in ethylene glycol favored the precipitation of $\beta$-TCP over monetite (Galea et al., 2013). Nevertheless, $\beta$-TCP nanoparticles have been synthesized at room temperature in methanol (Bow et al., 2004), which underlines the importance of the solvent. In organic solvents, the precipitation of phases such as brushite or HA may be prevented because they require the presence of either $\mathrm{H}_{2} \mathrm{O}$ molecules or $\mathrm{OH}^{-}$ions. The $\beta$-TCP materials synthesized through wet-chemical methods mentioned here were either not analyzed for $\mathrm{H}$ - for Ca-substitution (Galea et al., 2015; Bow et al., 2004) or exhibited only a small fraction of $\mathrm{HPO}_{4}^{2-}$ groups, as revealed by FTIR, according to the formula $\mathrm{Ca}_{2.98}\left(\mathrm{HPO}_{4}\right)_{0.04}\left(\mathrm{PO}_{4}\right)_{1.96}$ (Toyama et al., 2002). In contrast, the use of ethylene glycol and temperatures between 363 and $443 \mathrm{~K}$ resulted in much more significant hydrogen substitution.

Most $\mathrm{CaP}$ phases which precipitate in aqueous solution, e.g. CDHA, brushite or monocalcium phosphate monohydrate [MCPM, $\mathrm{Ca}\left(\mathrm{H}_{2} \mathrm{PO}_{4}\right)_{2} \cdot \mathrm{H}_{2} \mathrm{O}$ ], contain $\mathrm{HPO}_{4}^{2-}$ (or $\mathrm{H}_{2} \mathrm{PO}_{4}^{-}$) groups (Dorozhkin \& Epple, 2002), which thus parallels the incorporation of $\mathrm{HPO}_{4}^{2-}$ groups into platelets synthesized in ethy- 
lene glycol. At temperatures of $1273 \mathrm{~K}$ or more, $\mathrm{CaP}$ phases comprising $\mathrm{HPO}_{4}^{2-}$ groups are known to be thermally unstable. In the case of CDHA with a variable degree of $\mathrm{Ca}$ deficiency, $x$, calcination leads to the following transformation

$$
\begin{aligned}
& \mathrm{Ca}_{10-x}\left(\mathrm{HPO}_{4}\right)_{x}\left(\mathrm{PO}_{4}\right)_{6-x}(\mathrm{OH})_{2-x} \rightarrow \\
& (1-x) \mathrm{Ca}_{10}\left(\mathrm{PO}_{4}\right)_{6}(\mathrm{OH})_{2}+3 \times \mathrm{Ca}_{3}\left(\mathrm{PO}_{4}\right)_{2}+x \mathrm{H}_{2} \mathrm{O}(0<x \leq 1),
\end{aligned}
$$

where quantification of the weight fractions of the biphasic calcined sample allows for accurate determination of the initial degree of Ca deficiency (Ishikawa et al., 1993). The Cadeficient $\beta$-TCP platelets decomposed into $\beta$-CPP $(\mathrm{Ca} / \mathrm{P}=1)$ and $\beta$-TCP that exhibited no detectable Ca-deficiency when refined with the same structure model and no longer showed a band at $875 \mathrm{~cm}^{-1}$ in FTIR spectra (data not shown). Hence, the thermal decomposition during calcination can be described as

$$
\begin{aligned}
\beta-\mathrm{Ca}_{21-f_{m}}\left(\mathrm{HPO}_{4}\right)_{2 f_{m}}\left(\mathrm{PO}_{4}\right)_{14-2 f_{m}} \rightarrow & \left(7-f_{m}\right) \beta-\mathrm{Ca}_{3}\left(\mathrm{PO}_{4}\right)_{2} \\
& +f_{m} \beta-\mathrm{Ca}_{2} \mathrm{P}_{2} \mathrm{O}_{7}+f_{m} \mathrm{H}_{2} \mathrm{O} .
\end{aligned}
$$

The as-determined overall $\mathrm{Ca} / \mathrm{P}$ ratio of the biphasic sample coincided well with the refined $\mathrm{Ca} / \mathrm{P}$ ratio of the as-synthesized $\beta$-TCP sample, as well as with the elemental compositions determined by ICP-MS, which underlines the quantitative accuracy of the refinement model. Deprotonization and the precipitation of pyrophosphate was also observed when applying the refinement model to calcined synthetic Mgwhitlockite, which is in agreement with previous studies (Adcock et al., 2014).

The stoichiometry of the $\beta$-TCP platelets was independent of numerous synthesis parameters. Notably, neither the temperature nor the precursor $\mathrm{Ca} / \mathrm{P}$ ratio nor the total concentration had an effect on the final $\mathrm{Ca} / \mathrm{P}$ ratio in the crystals, indicating that the Ca deficiency is not the result of limited $\mathrm{Ca}$ ion supply or diffusion during crystallization. This conclusion is in line with the fact that the $\mathrm{Ca} / \mathrm{P}$ ratio was identical in platelets produced in glycerol, a solvent exhibiting a 30-fold lower ionic mobility compared with ethylene glycol due to its higher viscosity (Kameche et al., 2005). Also, since the final stoichiometry was independent of the reaction time (varying from $1 \mathrm{~min}$ to $24 \mathrm{~h}$ ), the Ca deficiency cannot be a result of Ca diffusing out of the crystals after their formation. Overall, these findings strongly suggest that the platelet structure is a thermodynamically stable and non-kinetically limited phase. This is in contrast with the precipitation of CDHA in aqueous solutions where the $\mathrm{Ca} / \mathrm{P}$ ratio can vary between 1.5 and 1.67 and is known to increase with increasing precursor $\mathrm{Ca} / \mathrm{P}$ ratio, reaction temperature and time (Raynaud et al., 2002; Ishikawa et al., 1993; Vallet-Regí et al., 1997). In particular, the $\mathrm{Ca} / \mathrm{P}$ ratio in CDHA gradually increases towards a thermodynamically more stable value (closer to 1.67) when incubated for longer time periods (Vallet-Regí et al., 1997). Moreover, the Ca/P ratio in CDHA varies with the solution $\mathrm{pH}$ (Vallet-Regí et al., 1997), whereas the acidity of ethylene glycol solutions did not influence the $\mathrm{Ca} / \mathrm{P}$ ratio in the platelets, even when approaching the stability region of the monetite phase. Interestingly, several of these synthesis parameters had a major effect on the platelet geometry, with the diameter and aspect ratio varying from 0.2 to $2 \mu \mathrm{m}$ and from 1 to 14 , respectively, as reported previously (Galea et al., 2013, 2014). Given this large range of surface-tovolume ratios in samples with almost identical $\mathrm{Ca} / \mathrm{P}$ ratios, the Ca deficiency is likely homogeneously distributed throughout the crystals. This finding is consistent with a previous study reporting that the center and edge region of the single crystals were crystallographically identical (Tao et al., 2008).

Owing to their controllable geometry and non-agglomerating properties, the platelets described in this study are of interest as fillers in nano-structured load-bearing composites or, at lower aspect ratios, may enhance the flowability of $\mathrm{CaP}$ pastes (Galea et al., 2013). The success of a bone substitute material relies on the solubility and degradation kinetics in aqueous environments, which are dependent on the crystal structure. In (CD)HA, a lower $\mathrm{Ca} / \mathrm{P}$ ratio, i.e. a higher degree of hydrogen substitution, is known to lead to a higher dissolution rate and an earlier precipitation of an apatite surface layer (Radin \& Ducheyne, 1993; Mavropoulos et al., 2003). In $\beta$-TCP and whitlockite, Mg plays an important role in the thermodynamic stability. Specifically, substitution of $8 \mathrm{~mol} \%$ $\mathrm{Ca}$ for $\mathrm{Mg}$ in $\beta$-TCP increases the thermal stability from $1423 \mathrm{~K}$ up to $1873 \mathrm{~K}$ (Enderle et al., 2005), while at low temperature $\mathrm{Mg}$ reduces the solubility of whitlockite below that of $\beta$-TCP and CDHA (Hamad \& Heughebaert, 1986). The stabilizing effect of $\mathrm{Mg}$ dominates any additional change in solubility resulting from the hydrogen substitution. On the other hand, the structure presented in this study is free of $\mathrm{Mg}$ and thus allows for an isolated analysis of the effect of hydrogen substitution on the solubility of $\beta$-TCP, which will be a priority in future studies.

Since $\beta$-TCP bone grafts often require more than a year for complete resorption (Van Der Pol et al., 2010), a material with a higher degradation rate than stoichiometric $\beta$-TCP may provide a clinical benefit in orthopaedic applications. Monetite and brushite materials exhibit very fast resorption but are associated with acidic $\mathrm{pH}$ changes when transforming into HA due to the presence of $\mathrm{HPO}_{4}^{2-}$ groups, which limits the volume of their application. Since $\mathrm{HPO}_{4}^{2-}$ groups represent only a fraction of the phosphate groups in platelets, weaker $\mathrm{pH}$ changes are expected compared with monetite or brushite. Therefore, a more soluble hydrogen-substituted $\beta$-TCP material may provide a faster resorbing, highly biocompatible alternative to stoichiometric $\beta$-TCP bone graft substitutes.

\section{Conclusions}

This study elucidated the crystal structure of $\beta$-TCP platelets precipitated in ethylene glycol. Rietveld refinement of XRD patterns indicated sub-occupied $\mathrm{Ca} 4$ and $\mathrm{O} 2$ atomic sites compared with the published $\beta$-TCP crystal model. In contrast, a model adopted from the whitlockite structure, where $\mathrm{Ca}$ is partly substituted by $\mathrm{H}$ along with the inversion of $\mathrm{P} \mathrm{O}_{4}$ tetrahedra, resulted in precise and reproducible refinements with stable convergence towards a $\mathrm{Ca} / \mathrm{P}$ ratio of $1.443 \pm 0.003(n=36)$ and was corroborated by the presence 
of $\mathrm{HPO}_{4}^{2-}$ absorptions in FTIR spectra. Calcination of the platelets led to phase separation into $\mathrm{H}$-free $\beta$-TCP $(\mathrm{Ca} / \mathrm{P}=$ $1.5)$ and $\beta$ - $\mathrm{CPP}(\mathrm{Ca} / \mathrm{P}=1.0)$ which served as a quantitative verification of the initially refined $\beta$-TCP $\mathrm{Ca} / \mathrm{P}$ ratio. Specifically, the global $\mathrm{Ca} / \mathrm{P}$ ratio closely matched the $\beta$-TCP Ca/P ratio before calcination $(\Delta \mathrm{Ca} / \mathrm{P}=0.003)$ and the chemical composition measured by ICP-MS $(\Delta \mathrm{Ca} / \mathrm{P}=0.003)$. The $\mathrm{Ca} / \mathrm{P}$ ratio was independent of synthesis parameters including temperature, time, $\mathrm{pH}$, precursor $\mathrm{Ca} / \mathrm{P}$ ratio and concentration, which indicates a thermodynamically stable phase. These findings describe for the first time a hydrogen-substituted $\beta$ TCP structure or, in other words, an Mg-free whitlockite and thus raise the question of the role of hydrogen substitution in $\beta$-TCP solubility.

\section{Related literature}

References cited in the supporting information include: Cerruti et al. (2014), Nuevo et al. (2006), Ping et al. (2001) and Tortet (1997).

\section{Acknowledgements}

This study was supported by the Swiss National Science Foundation (SNF; 200021_137589). The authors would like to thank Céline Lang for her assistance in the production of synthetic Mg-whitlockite as well as Delphine Pasche and Benjamin Andreatta for their contribution to the ICP-MS method development.

\section{References}

Adcock, C. T., Hausrath, E. M., Forster, P. M., Tschauner, O. \& Sefein, K. J. (2014). Am. Mineral. 99, 1221-1232.

Bergmann, J., Friedel, P. \& Kleeberg, R. (1998). IUCr Newsl. 20, 5-8. Berzina-Cimdina, L. \& Borodajenko, N. (2012). Infrared Spectroscopy - Materials Science, Engineering and Technology, edited by P. T. Theophile, pp. 123-148. Rijeka, Croatia: InTech Europe.

Bigi, A., Foresti, E., Gandolfi, M., Gazzano, M. \& Roveri, N. (1997). J. Inorg. Biochem. 66, 259-265.

Bohner, M. (2010). Mater. Today, 13, 24-30.

Boudin, S., Grandin, A., Borel, M. M., Leclaire, A. \& Raveau, B. (1993). Acta Cryst. C49, 2062-2064.

Bow, J. S., Liou, S. C. \& Chen, S. Y. (2004). Biomaterials, 25, 31553161.

Calvo, C. \& Gopal, R. (1975). Am. Mineral. 60, 120-133.

Cantwell, P. R., Tang, M., Dillon, S. J., Luo, J., Rohrer, G. S. \& Harmer, M. P. (2014). Acta Mater. 62, 1-48.

Cerruti, M., Magnacca, G., Bolis, V. \& Morterra, C. (2003). J. Mater. Chem. 13, 1279-1286.

Dickens, B., Bowen, J. S. \& Brown, W. E. (1972). Acta Cryst. B28, $797-$ 806.

Dickens, B., Schroeder, L. W. \& Brown, W. E. (1974). J. Solid State Chem. 10, 232-248.

Doebelin, N. \& Kleeberg, R. (2015). J. Appl. Cryst. 48, 1573-1580.

Dorozhkin, S. V. \& Epple, M. (2002). Angew. Chem. Int. Ed. 41, 31303146.

Durucan, C. \& Brown, P. W. (2000). J. Mater. Sci. Mater. Med. 11, 365371.

Enderle, R., Götz-Neunhoeffer, F., Göbbels, M., Müller, F. A. \& Greil, P. (2005). Biomaterials, 26, 3379-3384.

Fowler, B. O. (1974). Inorg. Chem. 13, 194-207.
Galea, L., Alexeev, D., Bohner, M., Doebelin, N., Studart, A. R., Aneziris, C. G. \& Graule, T. (2015). Biomaterials, 67, 93-103.

Galea, L., Bohner, M., Thuering, J., Doebelin, N., Aneziris, C. G. \& Graule, T. (2013). Biomaterials, 34, 6388-6401.

Galea, L., Bohner, M., Thuering, J., Doebelin, N., Ring, T. A., Aneziris, C. G. \& Graule, T. (2014). Acta Biomater. 10, 3922-3930.

Gibson, I. R., Rehman, I., Best, S. M. \& Bonfield, W. (2000). J. Mater. Sci. Mater. Med. 11, 533-539.

Gopal, R., Calvo, C., Ito, J. \& Sabine, W. K. (1974). Can. J. Chem. 52, $1155-1164$

Hamad, M. \& Heughebaert, J. C. (1986). J. Cryst. Growth, 79, 192197.

Hughes, J. M., Cameron, M. \& Crowley, K. D. (1989). Am. Mineral. 74, 870-876.

Hughes, J. M., Jolliff, B. L. \& Rakovan, J. (2008). Am. Mineral. 93, 1300-1305.

Ishikawa, K., Ducheyne, P. \& Radin, S. (1993). J. Mater. Sci. Mater. Med. 4, 165-168.

Jang, H. L., Jin, K., Lee, J., Kim, Y., Nahm, S. H., Hong, K. S. \& Nam, K. T. (2014). Am. Chem. Soc. Nano, 8, 634-641.

Jillavenkatesa, A. \& Condrate, R. A. (1998). Spectrosc. Lett. 31, 16191634

Kameche, M., Bouamrane, R., Derriche, Z. \& Blanco, M. C. (2005). Mol. Phys. 103, 1231-1239.

LeGeros, R. Z. (2002). Clin. Orthop. 395, 81-98.

LeGeros, R. Z., Daculsi, G., Kijkowska, R. \& Kerebel, B. (1989). Magnesium in Health and Disease, pp. 11-19. Hertfordshire: John Libbey \& Co. Ltd.

Lin, F. H., Liao, C. J., Chen, K. S., Su, J. S. \& Lin, C. P. (2001). Biomaterials, 22, 2981-2992.

Lin, F. H., Liao, C. J., Chen, K. S. \& Sun, J. S. (1998). Biomaterials, 19, 1101-1107.

Loomba, L. \& Bhupinder, S. S. (2015). J. Nanomat. Mol. Nanotech. 4, $1-12$.

Makarov, C., Gotman, I., Jiang, X., Fuchs, S., Kirkpatrick, C. J. \& Gutmanas, E. Y. (2010). J. Mater. Sci. Mater. Med. 21, 1771-1779.

Mavropoulos, E., Rossi, A. M., da Rocha, N. C. C., Soares, G. A., Moreira, J. C. \& Moure, G. T. (2003). Mater. Charact. 50, 203-207.

McCusker, L. B., Von Dreele, R. B., Cox, D. E., Louër, D. \& Scardi, P. (1999). J. Appl. Cryst. 32, 36-50.

Nuevo, M., Meierhenrich, U. J., Muñoz Caro, G. M., Dartois, E., D'Hendecourt, L., Deboffle, D., Auger, G., Blanot, D., Bredehöft, J. H. \& Nahon, L. (2006). Astron. Astrophys. 457, 741-751.

Penczek, S., Pretula, J., Kubisa, P., Kaluzynski, K. \& Szymanski, R. (2015). Prog. Polym. Sci. 45, 44-70.

Ping, Z. H., Nguyen, Q. T., Chen, S. M., Zhou, J. Q. \& Ding, Y. D. (2001). Polymer, 42, 8461-8467.

Pol, U. van der, Mathieu, L., Zeiter, S., Bourban, P. E., Zambelli, P. Y., Pearce, S. G., Bouré, L. P. \& Pioletti, D. P. (2010). Acta Biomaterialia, 6, 3755-3762.

Radin, S. R. \& Ducheyne, P. (1993). J. Biomed. Mater. Res. 27, 35-45.

Raynaud, S., Champion, E., Bernache-Assollant, D. \& Thomas, P. (2002). Biomaterials, 23, 1065-1072.

Rietveld, H. M. (1969). J. Appl. Cryst. 2, 65-71.

Sader, M. S., Lewis, K., Soares, G. A. \& LeGeros, R. Z. (2013). Mater. Res. 16, 779-784.

Sudarsanan, K. \& Young, R. A. (1969). Acta Cryst. B25, 1534-1543.

Tang, Z., Kotov, N. A., Magonov, S. \& Ozturk, B. (2003). Nat. Mater. 2 , 413-418.

Tao, J., Jiang, W., Zhai, H., Pan, H., Xu, R. \& Tang, R. (2008). Cryst. Growth Des. 8, 2227-2234.

Tao, J., Pan, H., Zhai, H., Wang, J., Li, L., Wu, J., Jiang, W., Xu, X. \& Tang, R. (2009). Cryst. Growth Des. 9, 3154-3160.

Toby, B. H. (2006). Powder Diffr. 21, 67-70.

Tortet, L., Gavarri, J. R., Nihoul, G. \& Dianoux, A. J. (1997). J. Solid State Chem. 132, 6-16.

Toyama, T., Nakashima, K. \& Yasue, T. (2002). Nippon Seramikkusu Kyokai Gakujutsu Ronbunshi, 110, 716-721. 


\section{research papers}

Vallet-Regí, M., Rodríguez-Lorenzo, L. M. \& Salinas, A. J. (1997). Solid State Ion. 101-103, 1279-1285.

Vereecke, G. \& Lemaître, J. (1990). J. Cryst. Growth, 104, 820-832.
Yoshida, K., Hyuga, H., Kondo, N., Kita, H., Sasaki, M., Mitamura, M., Hashimoto, K. \& Toda, Y. (2006). J. Am. Ceram. Soc. 89, 688690. 